\title{
Continental Transpression Evidence Checking along the Fault Dena: Iran, Middle Zagros
}

\author{
Ehsan Aziz' ${ }^{1}$, Mohsen Pourkermani2 ${ }^{*}$, Korus Yazdjerdi ${ }^{3}$, Ali Sorbi ${ }^{4}$ \\ ${ }^{1}$ Department of Geology, Science and Research Branch, Islamic Azad University, Tehran, Iran \\ ${ }^{2}$ Department of Geology, Islamic Azad University, Tehran North Branch, Tehran, Iran \\ ${ }^{3}$ Department of Geology, Islamic Azad University, Shiraz Branch, Shiraz, Iran \\ ${ }^{4}$ Department of Geology, Islamic Azad University, Karaj Branch, Karaj, Iran \\ Email: ^mohsen.pourkermani@gmail.com
}

How to cite this paper: Aziz, E., Pourkermani, M., Yazdjerdi, K. and Sorbi, A. (2016) Continental Transpression Evidence Checking along the Fault Dena: Iran, Middle Zagros. Open Journal of Geology, 6, 1069-1079. http://dx.doi.org/10.4236/ojg.2016.69080

Received: May 22, 2016

Accepted: September 6, 2016

Published: September 9, 2016

Copyright $\odot 2016$ by authors and Scientific Research Publishing Inc. This work is licensed under the Creative Commons Attribution International License (CC BY 4.0).

http://creativecommons.org/licenses/by/4.0/

\begin{abstract}
Dena Fault is one of the fundamental and main structures with more than $130 \mathrm{~km}$. One of the most important structural properties of this fault is changing in its trend so that at least three structural trends are detectable along this fault. Some continental transpression evidences along fault Dena are checked. These evidences are: Fold's axis has configuration step and mutual desire. Fold's axis average preferred orientation makes angles less than 45 degrees with preferred orientation of the boundary faults. Strike-slip faults are arranged overlapping and territory. $\mathrm{P}$ harmonic sections are more than harmonic sections R. In the central and southern parts the type is transpression Trust and in the northern part the type is transpression shear. In the present strike-slip component right lateral of this fault is dominant to its trust component and Fault function in the present era, is right lateral reverse.
\end{abstract}

\section{Keywords}

Dena Fault, Transpression, Strike-Slip, Zagros

\section{Introduction}

Deformation of Transpression happens in the strike-slip shears, shortening of strikeslip and shortening of normal shear zones [1]-[4]. Transpression word first was used by Harland, 1971 for slip oblique convergence between the two continental blocks, or a movement that was analyzable to two Convergent and right lateral components. If the plates' convergence between angle and their border is more than 20 degrees, deformation of Transpression will be called pure shear dominated and if less will be called deformation with simple shear dominated [5]. This happens in local analogy for example 
in Compressional curves in a strike-slip fault too [1] [6] [7]. In tectonic scale, Transpression move Plates due to the oblique convergence are shown by a fault zone or separate zones [8] [9].

\section{Discussion}

\subsection{Tectonically Position}

Zagros Mountain ranges are a collection with over $1500 \mathrm{~km}$ length and a width of 250 $400 \mathrm{~km}$ that wide from east Turkey to the Gulf of Oman and are connected to Makran subduction zone [10] (Figure 1). In fact Zagros is Arabic and Eurasia plate collision and deformation area of 3,000,000 square kilometers that is one of biggest deformation convergence areas on the earth [11]. This area of Iran is one of the key areas for Collisional processes and development plateaus and associated structures [12].

Paleogeography and seismology in the Zagros says that shortening and preferred orientation metamorphic basement with Vertical expansion (folds and lift) has sedimentary Phanerozoic cover [14]. This preferred orientation and vertical expansion are created because of Arabic plate convergence with Iran. The convergence rate of $\mathrm{mm} /$ year 29 by Vita finzi (1978) [15] up to $10 \mathrm{~mm} /$ year by Tatar (2004) [16] has been measured. Arabic and Iranian plate have convergence angle of $60^{\circ}$ degrees with plates dealing border [17]. Therefore convergence has 2 components:

1) Component parallel to the NW-SE Zagros [18] that cause the right-handed strike slip on the fault system.

2) Another component perpendicular to the Zagros that causes fold and thrust corrosion in the Zagros.

Fault Dena is one of fundamental and main structure in middle Zagros with over 130 $\mathrm{km}$ length. The most important structural features of this fault are changing its process

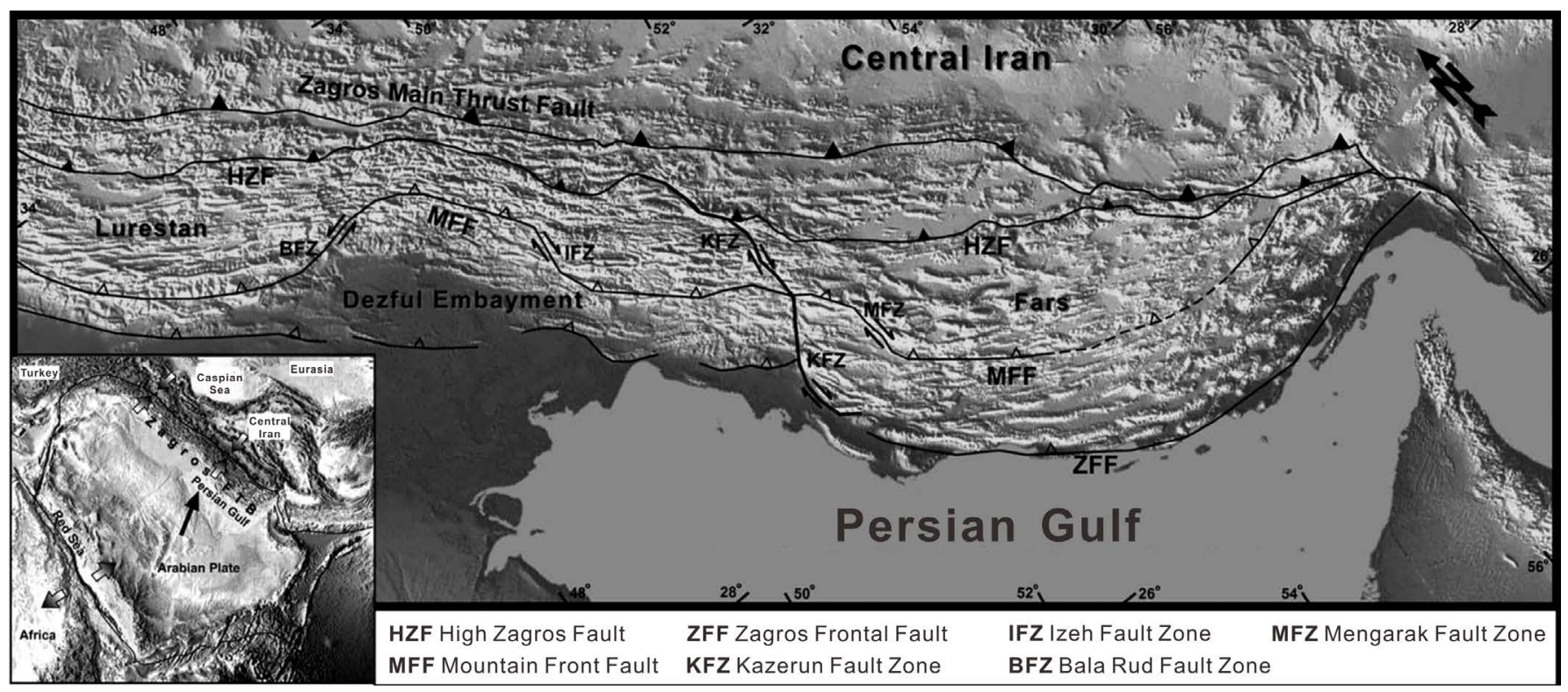

Figure 1. Topographic contours map and Structures and the main fault zone in Fold Iranian Zagros Thrust Belt [13]. 
in a way that during this process at least three structural processes are detectable. This fault starts from Highlands in $25 \mathrm{~km}$ of Yasuj northeast and near the northern terminus of the fault Kazeroon. This fault first, was in the shape of along with the structures general trends in Zagros having the Northwest-Southeast trend that in the pathway and after crossing the mountains Dena suffered a sudden turn about 38 degrees in the clockwise direction and was almost north-south extension. As fault get closer to the High Zagros and Ardal Fault changes trend and divided into several branches get northwestSouth East trend. This fault in its southern terminal is divided to two branches that one transfer part of deformation and movement from Kazeroon fault to Ardal and Sabzekooh fault by moving toward Kazeroun fault and the other one that get almost eastern-western trend in area, moves toward Zogros heights (Figure 2).

\subsection{Methods}

Fossen et al. 1994 consider geological Map and evidence and data field structure presentation, modeling of experimental and numerical modeling as three common ways to evaluate the deformation of Transpression. Some structural Transpression evidences with the experimental results of modeling in the desert are: 1) Fold by-step configuration and mutual desire that make fold's average preferred orientation axis with preferred orientation of the boundary faults angles less than 45 degrees; 2) The strike-slip

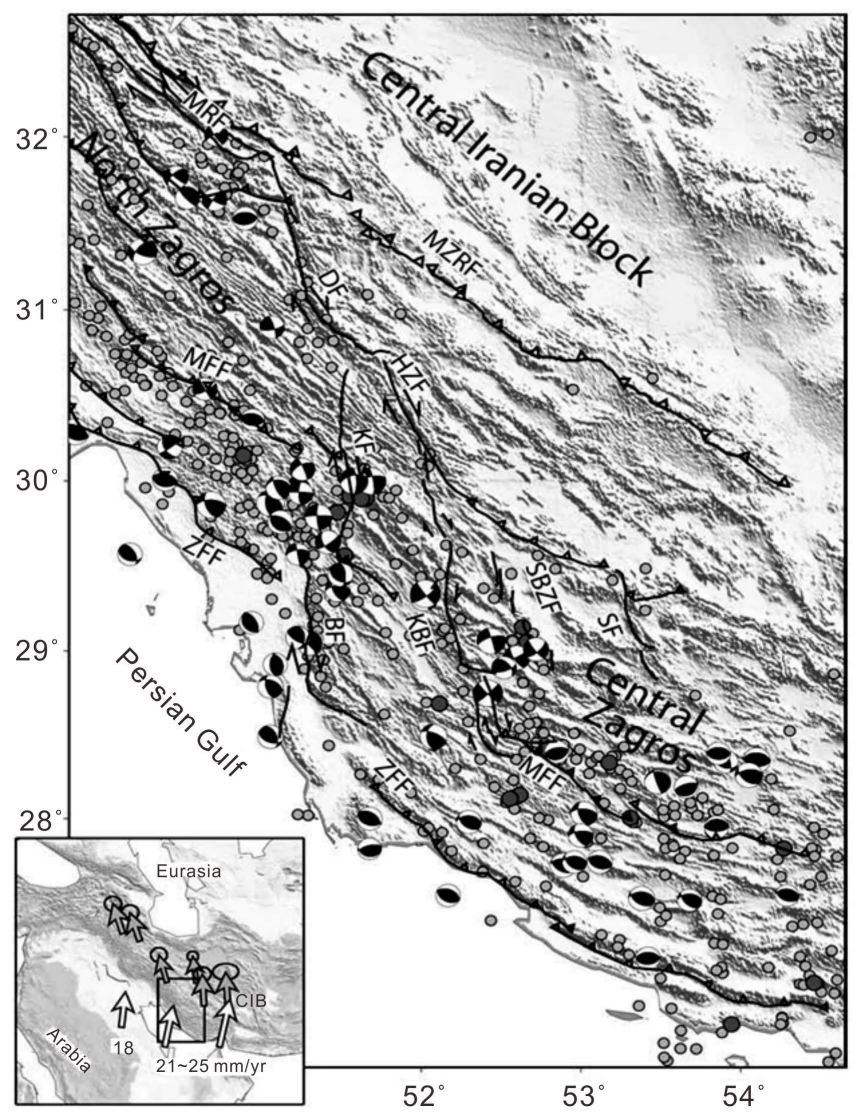

Figure 2. Map of active faults in South West Iran [19]. 
faults with overlapping arrangement; 3) P harmonic sections that is more abundant than harmonic sections R; 4) Find symmetrical structures Pop up; 5) The break-back sequence arrangement of faults in field observations all can be considered as documentary evidences of Transpression deformation. Drainage diversion around growing, collision regions is one common feature of the strike-slip with shortening component.

\subsection{Dena Fault Mechanism}

Dena fault motion mechanisms have been controversial and challenging topics in the central Zagros structural geology. Generally all the old comments about the mechanism of fault Dena is summed up in two general theories. According to the first theory fault, Dena had two mechanisms of action that the first consisted right round movement in Cambrian that this fault has been active again in quaternary reverse mechanism.

According to second theory, others believe that fault old and basic activities were in the form of reverse and were moving to the west that today's activities are testament to slip-strike [20]. In the map of 1,250,000 Boroojen with representing that fault Dena is eligible dip to the East believes this fault is a right-lateral reverse mechanism. Berbrian et al. 1981 believes that fault Dena has strike-slip. Field observations and study the map of the thickness [21] shows that this fault at least until the Eocene acted clearly as a border area of sedimentation and it's both sides' sediments have different thickness from each other. So it is only by having a large component of migration is possible (Figure 3).

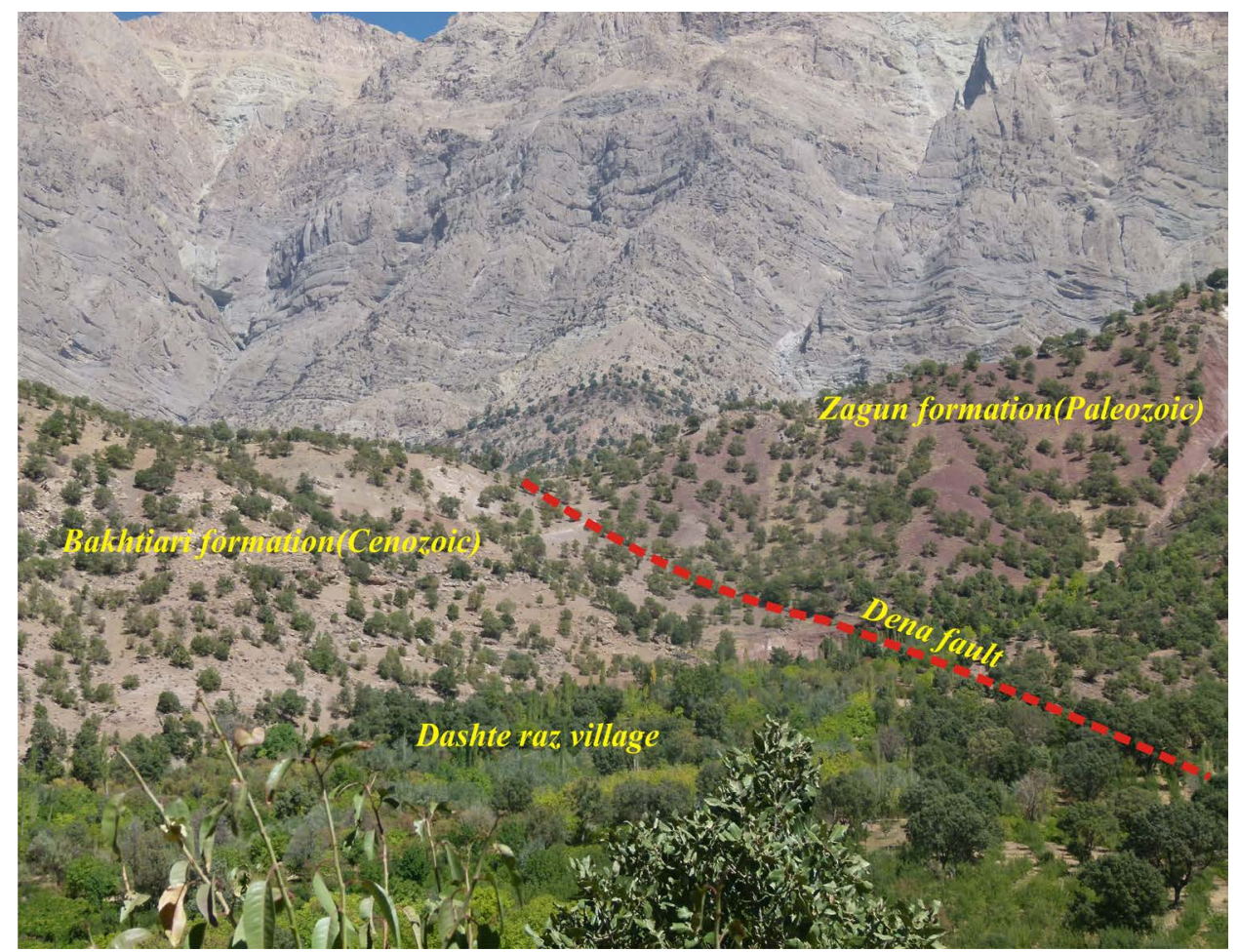

Figure 3. Dena fault condition in the village Dashteraz that shows strong performance of thrust faults Dena component and making Zagun formation and Bakhtiari formation near each other. 
This fault according to field observations and measurements of the new Geodesy [10] has a component of large slip-strike in the present age. Some field evidence for slipstrikes you can mention the creation of large offset along the rivers and streams cited (Figure 4).

Tavakoli et al. 2008 consider more than $13 \mathrm{~km}$ horizontal displacement for this fault based on geodesy measurements [10]. He considers the onset of strike movement from 2.6 to 4.3 million years for this fault. This fault has slip rates along three to five millimeters per year (Table 1).

Therefore it can be claimed that first this fault had thrust component till early Miocene that after collision of Iran and Saudi Arabia which happened following closing Neotethys this fault has been eligible of slip-strike components. So that now, right handed, right lateral component of this fault is dominant to its trust component and fault function in the present era, is right reverse.

\subsection{Geometry and Arrangement of Folds}

Folds' most important feature in the study area is the existence of overlapping folds to make the right staircase and double shaft. These folds have sigmoidal axial in general.

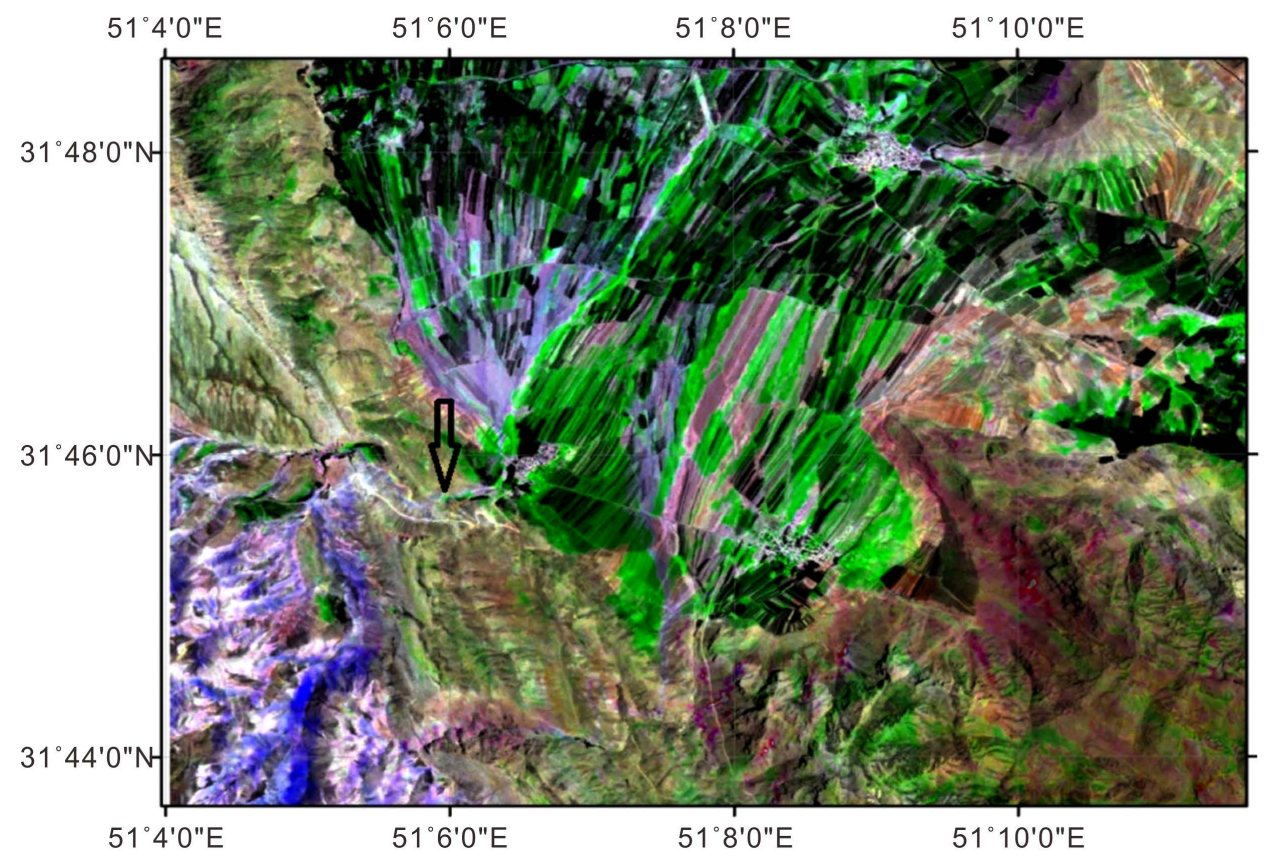

Figure 4. Change along the river channel along the fault Dena in TM satellite image.

Table 1. Dena horizontal slip rate and the horizontal movement start [10].

\begin{tabular}{cccccc}
\hline \multirow{2}{*}{ Fault } & \multirow{2}{*}{$\begin{array}{c}\text { Total } \\
\text { horizontal slip }\end{array}$} & $\begin{array}{c}\text { Age of } \\
\text { Fault Onset }\end{array}$ & $\begin{array}{c}\text { Average } \\
\text { Geological }\end{array}$ & GPS Derived & GPS Inferred \\
\cline { 3 - 5 } & & Slip Rate & Slip Rate & \\
\hline \multirow{2}{*}{ Dena } & $13 \mathrm{~km}$ & $2.6-4.3 \mathrm{ma}$ & $3-5 \mathrm{~mm} / \mathrm{yr}$ & $2.9-4.5 \mathrm{~mm} / \mathrm{yr}$ & $\mathbf{2 . 8}-\mathbf{4 . 5} \mathrm{ma}$ \\
\hline
\end{tabular}


This feature can be the result of right-strike transpression [12] [22]. These folds axis generally make angle less than 45 degrees with boundary shear zones (Figure 5).

Other structural features of continental environments Transpression is development of fault fold progress. As it was seen in Lab observations, leading fault folds develop in convergence angle $30 \leq \alpha \leq 90$ and is determined with symmetric stretching lift that Indicates a fault geometry leading fold with containing tilted edge-slip faults. From the folds with fault progress pattern in the study area we can mention Ben shahi anticline trending approximately eastern-western (Figure 6).

From the other structures we can mention the formation of relevant folds with fault geometry that in southern and central part of fault the folds are usually the type of fault bends and make Homocline that in this research we called that Homocline saver. Homocline Saver constituent classes have two different strikes. Older Jurassic formations' strike mainly is $\mathrm{N} 319^{\circ}$ And newer Jurassic formations' strike are $\mathrm{N} 355^{\circ}$. In fact Homocline saver is block segment of the fault Dena hanging wall with strike N330 that has emerged as a fault bend fold. Its surface effect is the proximity of very old rocks such as Precambrian-Paleozoic beside new rocks such as conglomerate Bakhtiari or Gachsaran evaporative sedimentary rocks, and AsmaricalcareousPic 3. Homocline Saver formation with its adjacent syncline (saver syncline in east of Homocline) represents the existence of Ramp geometry (under Homocline) felt (under syncline) for fault Dena in depth (Figure 7).

\subsection{Fractures}

Among the types of related structures to faults qualified components strike-slip in transpression situations we can mention further development of a variety of shear-type

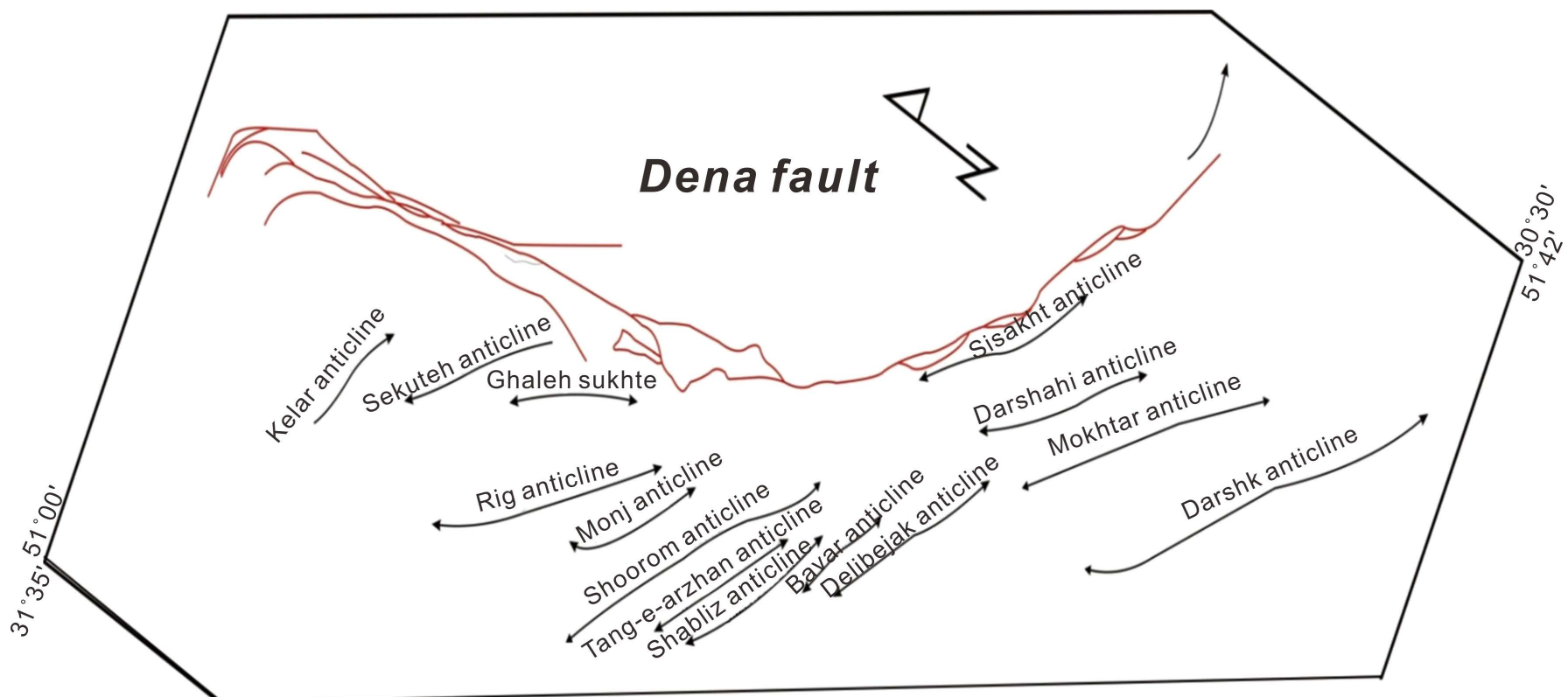

Figure 5. Status of Dena fault in orogenic Zagros belt that fold axis Dena fault bordering location shows the arrangement of overlapping is observable very well. 


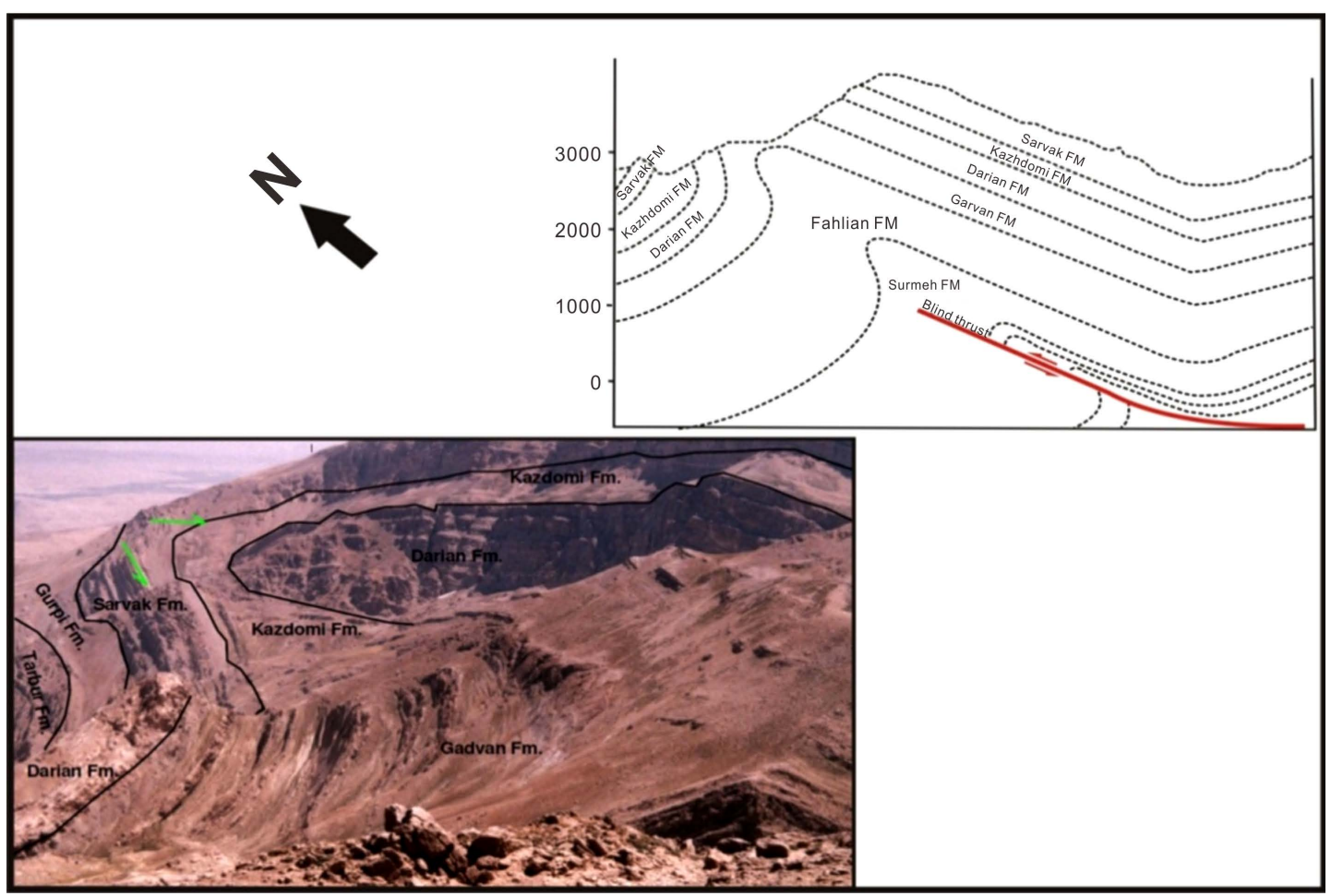

Figure 6. Ben shahi anticline position with the constituent formations of them.

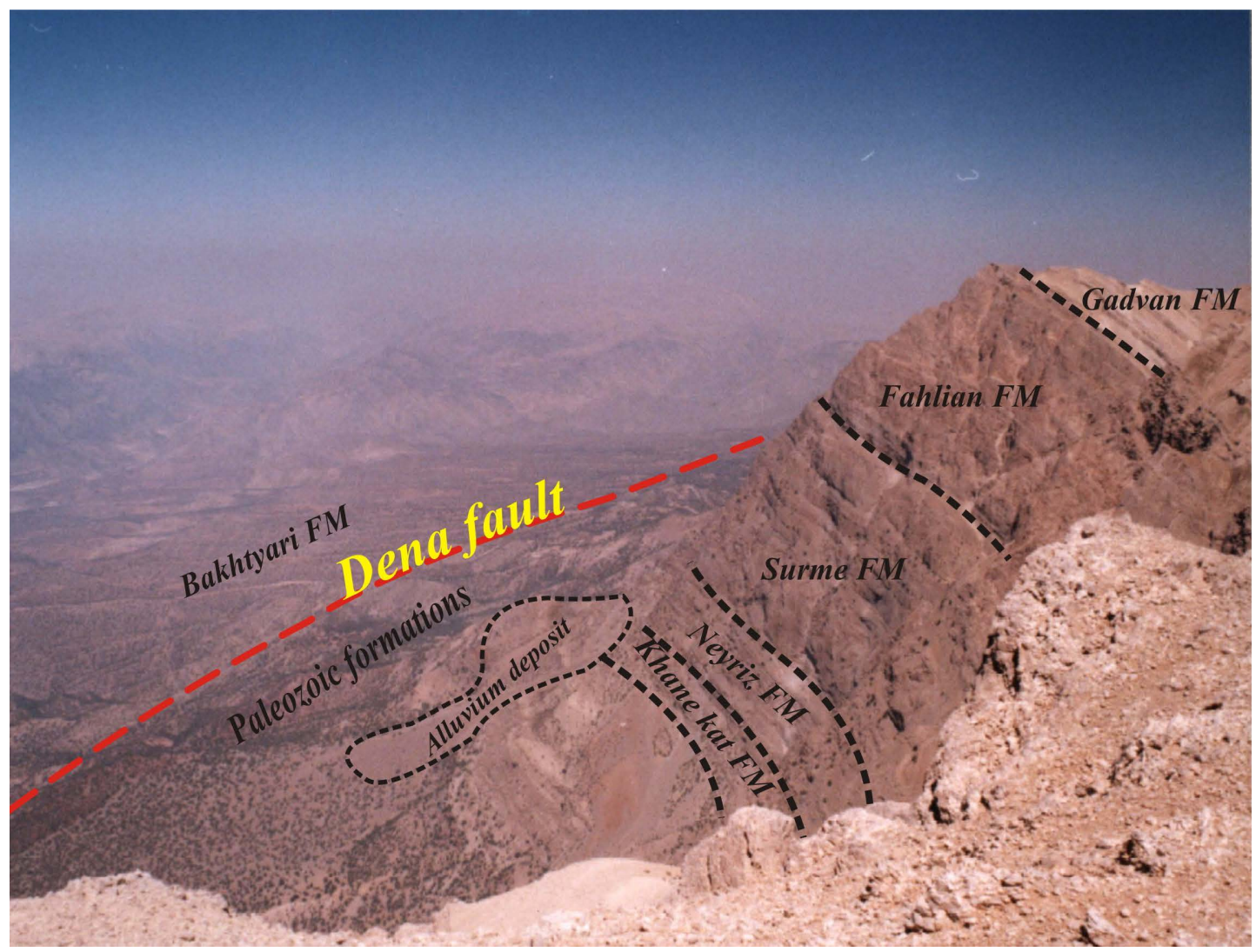

Figure 7. Homocline Saver Image and its formation and fault Dena position on the ground. 
$\mathrm{R}$ or Riddle shear to shear-type P. In this research, Fractures situation in three parts of fault northern, central and southern has been studied and Joint Journalism for checking $\mathrm{R}$ and $\mathrm{P}$ fractures and original faults in the project scope. As is also clear from fractures stereograms, clearly $\mathrm{P}$ harmonic sections were higher than $\mathrm{R}$ fractures and are present as the dominant fracture (Figure 8).

Other related structures related to fault Dena strike fractures is break-back sequence arrangement along this fault (Figure 9). Development of the sequence of faults in area is a result of an increase in the angle of convergence that younger steep faults in the hanging wall of older fault is created in it that development of a new generation of fault causes covering older faults below risen sediments from deposition and erosion in the hanging wall blocks.

From other observed structure in area Pop up structures can be mentioned that these structures are from relevant structures to strike-slip regime with compression (Figure 10). These structures happen in Convergence angle of 30 degree. This structure is observable in areas that fault is outside of main Zagros strike and it takes approximately north-south trend.

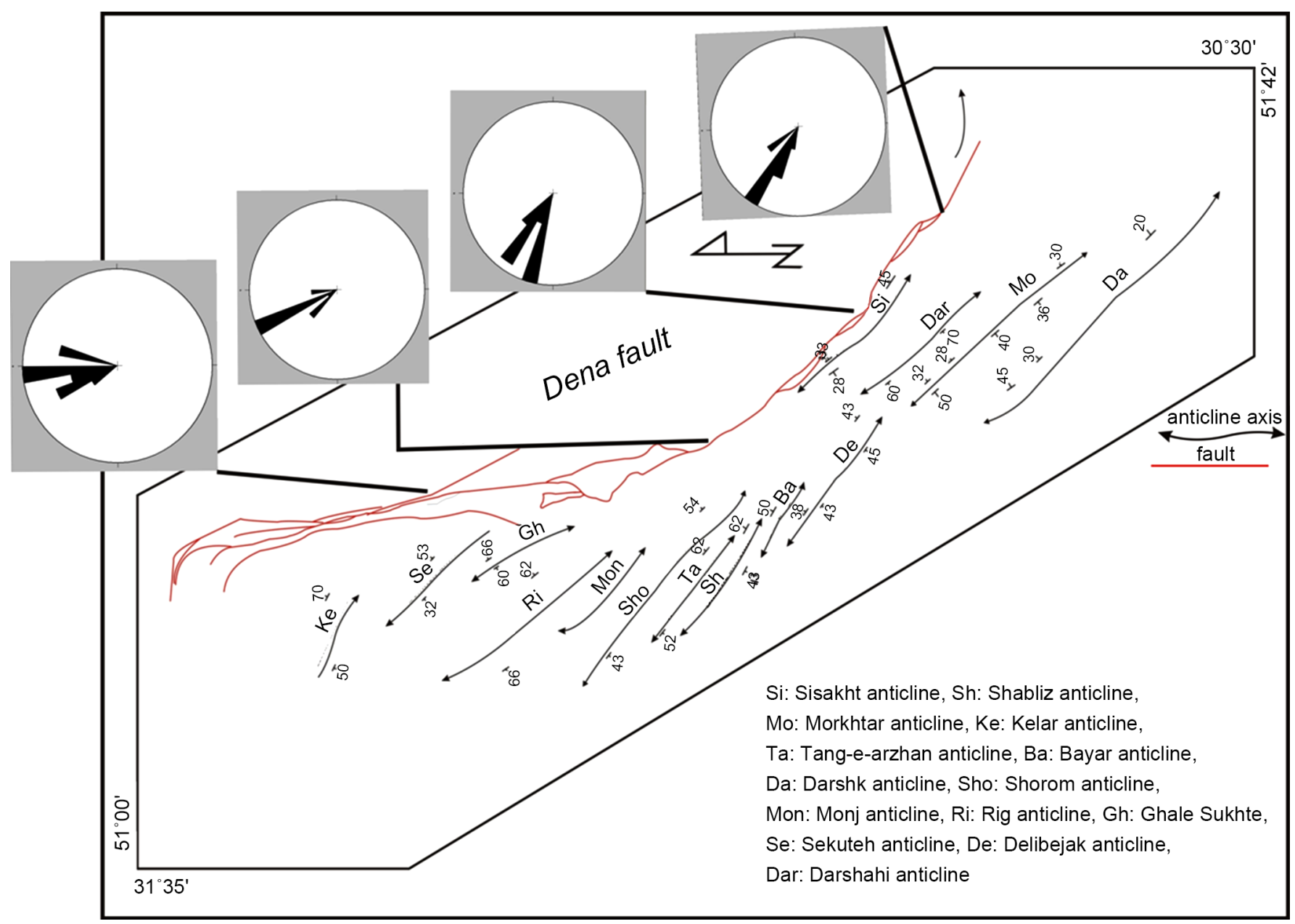

Figure 8. Rose diagram of fractures in the study area in different parts of the fault Dena. 


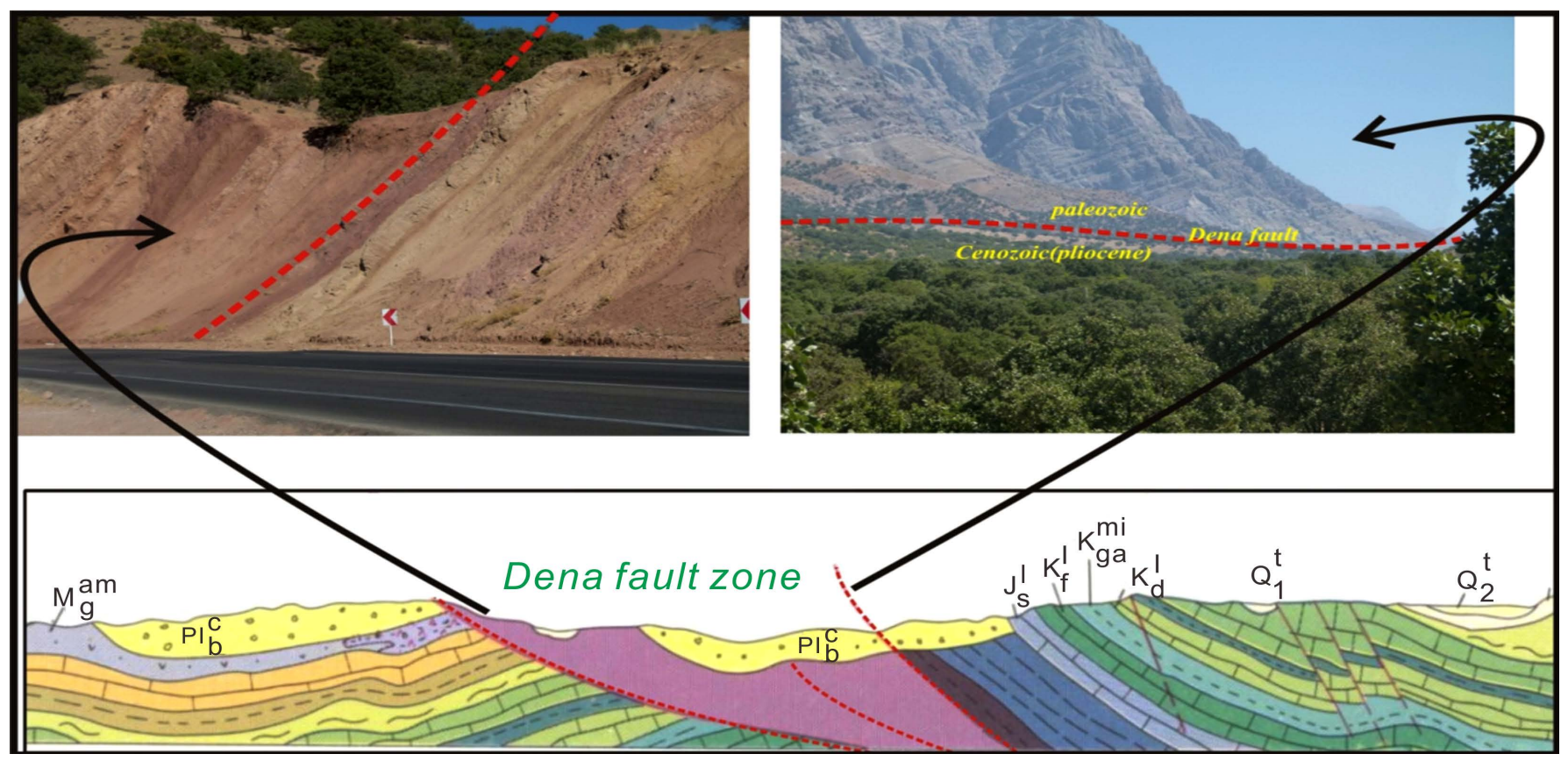

Figure 9. Break-back sequence arrangement and new formation of steep faults in hanging wall in cross-section of the fault Dena.

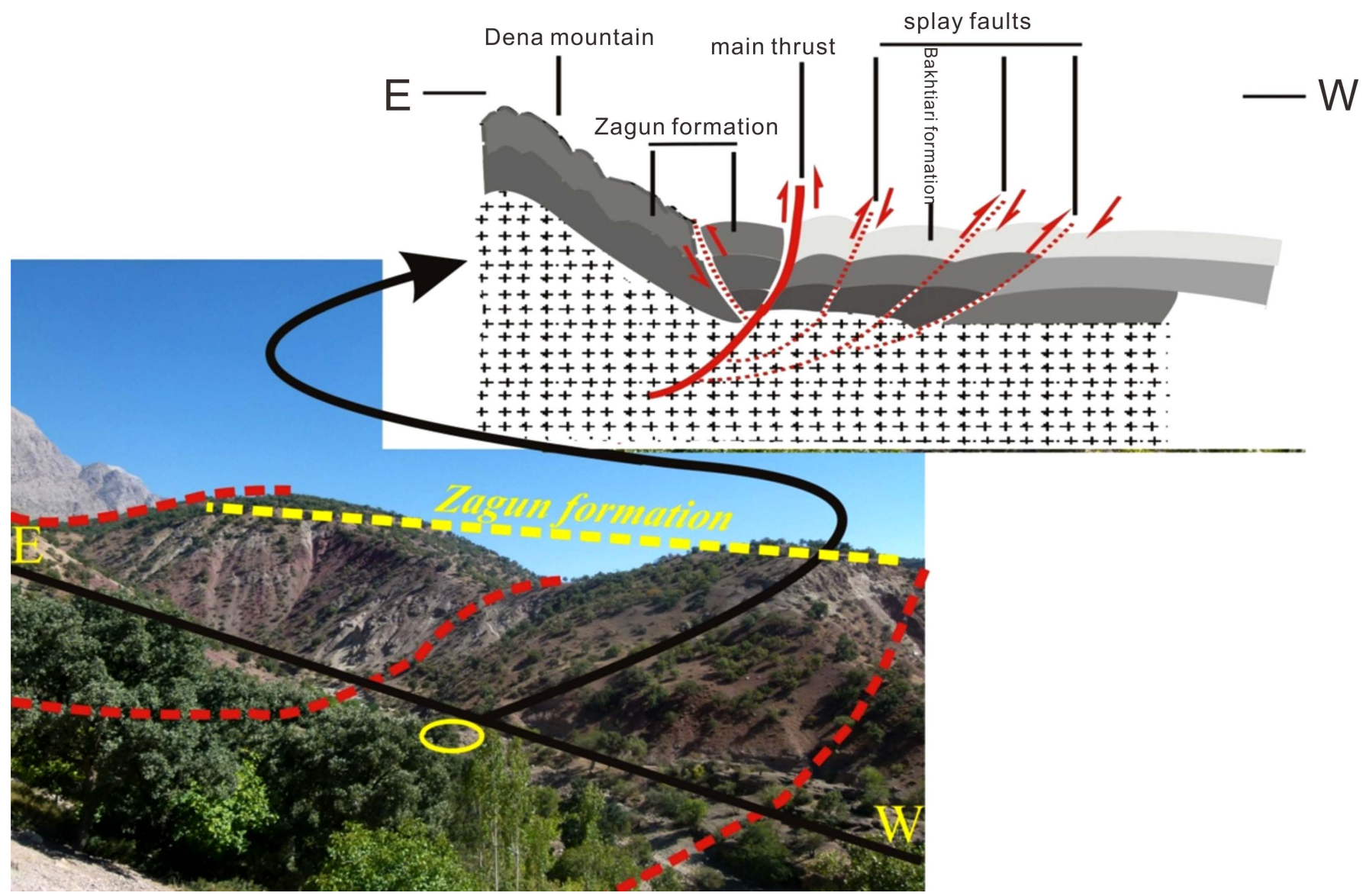

Figure 10. Pop up structure in Dena fault strike in Absiah village that caused removing the top formations and emerging Zagun formation. View towards the East. 


\section{Acknowledgements}

According to field studies, it seems that fault Dena owes its slip-strike component and beginning of transpression regime to the motion that happens for it after Arabic plate collision. Thus, the reverse dip-slip movement is related to before the time of Miocene and collision of the Arabian plate with the Eurasian. In each three segments of the fault Dena the stress situation has been a Transpression kind. That is in central and southern parts of transpression thrust and the northern part of the shear transpression. Now, right lateral component of this fault is dominant to its thrust component and fault function in the present era, is right reverse. Fractures Stereo phonograph also shows that clearly $\mathrm{P}$ harmonic sections are higher than $\mathrm{R}$ fractures and is present as the dominant fracture in area. In central and southern part of fault folds, they are usually fault bend and the fault progress kind. Other related structures along the fault Dena fractures break-back sequence arrangement can be mentioned in this fault strike. Development of this fault sequence in area is the result of increase in the angle of convergence that steeper younger faults are created in older faults hanging wall. Development of new generation of faults causes covering older faults below risen sediments from deposition and erosion in the hanging wall blocks.

\section{References}

[1] Sanderson, D.J. and Marchini, R.D. (1984) Transpression. Journal of Structural Geology, 6, 449-458.

[2] Teyssier, C. and Tikoff, B. (1998) Strike-Slip Partitioned Transpression of the San Andreas Fault System: A Lithospheric-Scale Approach. In: Holdsworth, R.E., Strachan, R.A. and Dewey, J.F., Eds., Continental Transpressional and Transtensional Tectonics, Vol. 135, Geological Society of London Special Publication, London, 143-158.

[3] Dewey, J.F., Holdsworth, R.E. and Strachan, R.A. (1998) Transpression and Transtension Zones. In: Holdsworth, R.E., Strachan, R.A. and Dewey, J.F., Eds., Continental Transpressional and Transtensional Tectonics, Geological Society Special Publication, London, 1-13.

[4] Jones, R.R., Holdworth, R.E., Clegg, P., McCaffrey, K. and Tavernelli, E. (2004) Inclined Transpression. Journal of Structural Geology, 26, 1531-1548. http://dx.doi.org/10.1016/j.jsg.2004.01.004

[5] Fossen, H., Tikoff, B. and Teyssier, C. (1994) Strain Modelling of Transpressional and Transtensional Deformation. Norsk Geologisk Tidsskrift, 74, 134-145.

[6] Davison, I. (1994) Linked Fault Systems: Extensional, Strike-Slip and Contractional. In: Hancock, P.L., Ed., Continental Deformation, Pergamon Press, Oxford, 121-142.

[7] Keller, J.V.A., Hall, S.H. and McClay, K.R. (1997) Shear Fracture Pattern and Microstructural Evolution in Transpressional Fault Zones from Field and Laboratory Studies. Journal of Structural Geology, 19, 1531-1548. http://dx.doi.org/10.1016/S0191-8141(97)00042-4

[8] Tikoff, B. and Teyssier, C. (1994) Strain Modelling of Displacement-Field Partitioning in Transpressional Orogens. Journal of Structural Geology, 16, 1575-1588.

[9] Jones, R.R. and Tanner, P.W. (1995) Strain Partitioning in Transpression Zones. Journal of Structural Geology, 17, 793-802.

[10] Tavakoli, F., Walpersdorf, A., Authemayou, C., Nankali, H.R., Hatzfeld, D., Tatar, M., Djamour, Y., Nilforoushan, F. and Cotte, N. (2008) Distribution of the Right-Lateral Strike-Slip 
Motion from the Main Recent Fault to the Kazerun Fault System (Zagros, Iran): Evidence from Present-Day GPS Velocities. Earth and Planetary Science Letters, 275, 342-347. http://dx.doi.org/10.1016/j.epsl.2008.08.030

[11] Allen, M., Jackson, J. and Walker, R. (2004) Late Cenozoic Reorganization of the Arabia Eurasia Collision and the Comparison of Short-Term and Long-Term Deformation Rates. Tectonics, 23, 1-16.

[12] Sarkarinejad, K. and Azizi, A. (2008) Slip Partitioning and Inclined Dextral Transpression along the Zagros Thrust System, Iran. Journal of Structural Geology, 30, 116-136. http://dx.doi.org/10.1016/j.jsg.2007.10.001

[13] Sepehr, M. and Cosgrove, J.W. (2004) Structural Framework of the Zagros Fold-Thrust Belt, Iran. Marine and Petroleum Geology, 21, 829-843. http://dx.doi.org/10.1016/j.marpetgeo.2003.07.006

[14] Berberian, M. (1995) Master Blind Thrust Faults Hidden under the Zagros Folds: Active Basement Tectonics and Surface Morphotectonics. Tectonophysics, 241, 193-224. http://dx.doi.org/10.1016/0040-1951(94)00185-C

[15] Vita-Finzi, C. (2001) Rates Neotectonics in the Arabian Plate Margine. Journal of Structural Geology, 25, 521-533. http://dx.doi.org/10.1016/S0191-8141(00)00117-6

[16] Tatar, M., Hatzfield, D. and Ghafory-Ashtiyani, M. (2004) Tectonics of the Central Zagros (Iran) Deduced from Microearthquake Seismicity. Geophysical Journal International, 156, 255-266. http://dx.doi.org/10.1111/j.1365-246X.2003.02145.x

[17] Alavi, M. (2007) Structures of Zagros Fold-Thrust Belt in Iran. American Journal of Science, 307, 1064-1095. http://dx.doi.org/10.2475/09.2007.02

[18] Vernant, P., Nilforoushan, F., Chery, J., Bayer, R., Djamour, Y., Masson, F., Nankali, H., Ritz, J.J.F., Sedighi, M. and Tavakoli, F. (2004) Deciphering Oblique Shortening of Central Alborz in Iran Using Geodetic Data. Earth and Planetary Science Letters, 223, 177-185.

[19] Bachmanov, D.M., Trifonov, V.G., Hessami, Kh.T., Kozhurin, A.I., Ivanova, T.P., Rogozhin, E.A., Hademi, M.C. and Jamali, F.H. (2004) Active Faults in the Zagros and Central Iran. Tectonophysics, 380, 221-241.

[20] Alavi, M. (2004) Regional Stratigraphy of the Zagros Fold-Thrust Belt of Iran and Is Proforland Evolution. American Journal of Science, 340, 1-20. http://dx.doi.org/10.2475/ajs.304.1.1

[21] Sherkati, S. and Letouzey, J. (2004) Variation of Structural Style and Basin Evolution in the Central Zagros (lzeh Zone and Dezful Embayament), Iran. Marine and Petroleum Geology, 21, 535-554. http://dx.doi.org/10.1016/j.marpetgeo.2004.01.007

[22] Tikoff, B. and Peterson, K. (1998) Physical Experiments of Transpressional Folding. Journal of Structural Geology, 20, 661-672. 
Submit or recommend next manuscript to SCIRP and we will provide best service for you:

Accepting pre-submission inquiries through Email, Facebook, LinkedIn, Twitter, etc. A wide selection of journals (inclusive of 9 subjects, more than 200 journals)

Providing 24-hour high-quality service

User-friendly online submission system

Fair and swift peer-review system

Efficient typesetting and proofreading procedure

Display of the result of downloads and visits, as well as the number of cited articles

Maximum dissemination of your research work

Submit your manuscript at: http://papersubmission.scirp.org/

Or contact ojg@scirp.org 